\title{
Exploring teachers' curriculum decision making: insights from history education
}

Article

Accepted Version

Harris, R. and Reynolds, R. (2018) Exploring teachers' curriculum decision making: insights from history education. Oxford Review of Education, 44 (2). pp. 139-155. ISSN 03054985 doi: https://doi.org/10.1080/03054985.2017.1352498 Available at https://centaur.reading.ac.uk/71514/

It is advisable to refer to the publisher's version if you intend to cite from the work. See Guidance on citing.

To link to this article DOI: http://dx.doi.org/10.1080/03054985.2017.1352498

Publisher: Taylor \& Francis

All outputs in CentAUR are protected by Intellectual Property Rights law, including copyright law. Copyright and IPR is retained by the creators or other copyright holders. Terms and conditions for use of this material are defined in the End User Agreement.

\section{www.reading.ac.uk/centaur}

\section{CentAUR}

Central Archive at the University of Reading

Reading's research outputs online 


\section{Exploring teachers' curriculum decision making: insights from history education}

Richard Harris \& Rosemary Reynolds

Institute of Education, University of Reading, Reading, UK

r.j.harris@ reading.ac.uk

ORCID ID orcid.org/0000-0001-8606-5515, Twitter@RH47R

Tel 01183782725

Richard Harris is an associate professor in history education. His interests are mainly related to the history curriculum, how it is perceived and conceptualised, as well as the place of diversity within the history curriculum and the public and political discourse around history education.

Rosemary Reynolds was a doctoral research student at the Institute of Education, University of Reading. Her interests are history and sociology, and in particular minority ethnic groups studying in the UK. Her thesis, a work in progress, explores Chinese A-level students in FE colleges; their experiences, expectations and decision-making. 


\section{Exploring teachers' curriculum decision making: insights from history education}

This paper explores teachers' decision making by examining the topics that 11 history teachers from ten schools in England chose to teach and how they approached teaching these topics. Data were gathered from curriculum documents and semi-structured interviews in which teachers' topic choices and approaches to history were explored. Most teachers adopted a disciplinary approach to history teaching but one focused on analytical structures rather than processes. Additionally the findings suggest a large degree of uniformity in the topics chosen despite the freedom provided within the policy documents for history teaching in England. Few teachers had given much consideration to approaches that demonstrate the 'usability' of history for young people. This suggests a need to engage teachers more fully in robust curriculum debates given their central role in enacting curricula.

Key words: history curriculum; knowledge; teacher decision making; curriculum; curriculum design

\section{Introduction}

Constructing a curriculum is an important task because the curriculum 'offer(s) opportunities for pupils of all ages to move beyond the experience they bring to school and to acquire knowledge that is not tied to that experience' (Young, 2014, pp.8-9).

A central curriculum debate is about the type of knowledge that is to be conveyed or developed through education. Broadly speaking this debate is about the extent to which there should be a focus on knowledge about the process of learning (i.e. 'learning how to learn' knowledge), mastery of a body of substantive knowledge (which is seen as developing 'cultural capital'), and/or developing a disciplinary understanding of a subject (which implies a familiarity with and capacity to use subject specific concepts that structure knowledge and an understanding of how claims to knowledge are constructed). As Sears (2017) recognises these debates are universal, but solutions reflect regional and national contexts (and even within particular contexts the situation is never going to be uniform). 
This knowledge debate exists across subject communities. For example in English education Anderson (2015) critiques both the 'cultural capital' and disciplinary models, and in modern languages debate has revolved around mastery of grammatical knowledge versus the development of communicative competence (Macaro, 2014). The debate about knowledge is particularly contentious and politicised in history education given the perceived role history has in shaping collective memories (e.g. Nakou \& Barca, 2010; Sandwell, 2012).

Teachers play a key role in the process of curriculum making, as teachers are the intermediaries who interpret and enact the curriculum, even where it is heavily prescribed (e.g. Monte-Sano, de la Paz \& Felton, 2014). Yet while teachers have this important role, surprisingly little is known about how they turn these official policies into school level curricula. Knowing what teachers choose to include in their curriculum, how they arrive at these decisions and what they believe they are attempting to do through teaching particular content will fill an important gap in our understanding of teachers' decision making. This concern with decision making is reflected in a growing number of small-scale studies of history teachers from around the world, exploring how disciplinary concepts are used in Spain (Cercadillo, 2015), and the content choices teachers make in New Zealand (Ormond (2016) and in the US (Swalwell, Pellegrino and View, 2015).

Understanding teachers' decision making is useful for a number of reasons. Meaningful professional development and improved classroom practice are difficult to design without understanding how and why teachers make the decisions they do about curriculum content (Boschman, McKenney \& Voogt, 2014). Second, these insights can help guide policy development and teacher education. Finally, knowing how teachers think about curriculum is a necessary precursor to involving teachers in exploring their own process of curriculum design and how they aim to develop students' knowledge through this process. It can be argued that this knowledge of teachers' thinking is particularly needed at a time when 
teachers are increasingly seen as 'skilled technicians', rather than as 'intellectuals' (Mitchell \& Lambert, 2015, p.367) engaged in curriculum development.

\section{The context of history teaching in England}

This study was conducted in England in 2015-16, so it is helpful to understand the policy landscape at that time. In England the National Curriculum covers the 5-14 age range (although increasingly schools only apply the curriculum to those aged 13 or under). The 1114 (or 13) age range covers lower secondary schooling (known as Key Stage 3 or KS3), where history is compulsory. At 13 or 14 students start public examination courses, where for most students history becomes an optional subject. Thus for the majority of students there are only two or three years where they are all entitled to specialist history teaching. Additionally there are no guidelines as to how much curriculum time should be given to the subject. These structural issues mean teachers have to construct a curriculum that is coherent for those who will not pursue the subject any further and that will provide an appropriate foundation for those continuing with further study.

A new history National Curriculum was introduced in 2014 (DfE, 2013b), whilst a new public examination course was due to begin in 2016 . The study therefore occurred at a time when history teachers had potentially to rethink their curriculum. This provided an opportunity to examine what they felt was important to teach.

The new curriculum (DfE, 2013b) outlines key periods to be taught (largely focused on Britain history) but generally leaves teachers latitude to choose specific content. Some schools have even greater freedoms; since 2010 the government has encouraged the growth of 'academy' and 'free' schools, which are state-funded but not required to teach the National Curriculum in any subject. In such schools history teachers have complete freedom over decisions about what should be taught in their curriculum. 


\section{Literature review}

Within history education, debates about the curriculum and type of knowledge to be developed can be framed around three issues; history as a form of knowledge; specific content that is considered significant; the 'usability' of specific content.

\section{Forms of knowledge}

The debate about history as a form of knowledge is linked to a broader argument about different types of subject knowledge that could be developed. Young and Muller (2010) distinguish between three educational 'futures'. 'Future 1' presents a model where substantive knowledge is valued, and existing knowledge, defined by the elite, is taught as unproblematic and uncontested/incontestable knowledge. For some this should be the driving force of any curriculum. Hirsch (1987) is an advocate of 'cultural literacy', arguing that mastering a body of knowledge allows young people to develop a common shared cultural literacy. Within history education this would reflect what Seixas (2007) has termed a 'collective memory' approach. Essentially students are taught 'a coherent, meaningful story of the collective past, which will help to shape a common identity, defined by common experience and belief' (Seixas, 2007, p.20). The focus is on presenting a single, accepted version of the past. An approach such as this would typically emphasise knowledge of events and individuals deemed to be historically significant.

'Future 2' focuses on students 'learning how to learn'. This approach values the development of generic competences unrelated to specific knowledge and any reason why particular knowledge is deemed valuable. It means however that learners' development is constrained by the level of their own experience. Both 'Future 1' and '2' models have been challenged as the basis on which to build a history curriculum, as they present 'the twin dangers of an authoritarian imposition of the prescribed version of the past, or an absurd and 
destructive relativism in which any version of the past, is assumed to be as valid (or invalid) as any other' (Harris \& Burn, 2011, p.257).

'Future 3', in contrast, is underpinned by a strong disciplinary focus, that is linked to understanding how claims to knowledge are made - this is described as 'powerful knowledge' because it allows young people to understand how knowledge is constructed, and is therefore open to debate (Young, 2011). As Cain and Chapman (2014) argue, this approach is appropriate in history education as it recognises that history is both a body and form of knowledge, and that any claims to knowledge are based upon discipline-specific ways of thinking. This includes the understanding of second-order concepts (such as cause and consequence, change and continuity, which are used to shape and explain the past) and the process of re-constructing the past, using sources critically, and how and why different interpretations of the past come to be. These disciplinary ideas can be detected in all iterations of the history National Curriculum in England, but the terms concepts and processes, to denote how the discipline works, were used in the 2008 version (QCA, 2007). The distinction between concepts and processes is not always entirely clear, for example Ashby (2017) argues that working with sources is not just a process, as students need to have a conceptual understanding of how evidence is used.

Although a focus on disciplinary knowledge has been criticised for promoting esoteric knowledge, irrelevant to students' lives (Barton, 2009; Beck, 2013), Young (2013, p.96) argues that disciplinary enquiry provides 'the best understanding of the natural and social worlds that we have'. He however acknowledges the pedagogical challenges his model presents and regards this as a central concern for future research.

\section{Choosing content that is seen as significant}

Although debates about history as a form of knowledge are well developed (e.g. Cain \& 
Chapman, 2014), debates about what body of substantive knowledge is appropriate are less well explored. There is research that has investigated what teachers believe to be the goals of history education (e.g. Harris, 2012), views which are likely to shape the choices made about curriculum content, but the exact nature of those choices has been explored less extensively.

One of the few studies that has explored history teachers' thinking in-depth, was conducted by Husbands, Kitson and Pendry (2003). As part of the study, the eight teachers involved were asked explicitly what should be taught in the curriculum, and were all loath to be prescriptive; however when pushed they identified the Norman Conquest, the English Reformation, the English Civil War and the two World Wars as significant topics. Harris and Burn's (2016) analysis of 544 survey responses to the 2013 curriculum proposals for England (DfE, 2013a) presents the views of a larger number of teachers but shows what teachers would not want to teach, rather than a positive affirmation of what they would like to teach. However the teachers' responses suggested that they disliked the proposed curriculum for: focusing too narrowly on British history; presenting (potentially) an overly favourable record of British achievements in the past; being too heavily weighted towards political history; and failing to recognise the diverse, multicultural nature of Britain's past. This would suggest that teachers prefer to teach a curriculum that includes both national and wider world history, critiques Britain's role in the past, covers a range of types of history, and includes topics that reflect past movement and interactions of different groups of people. Although this piece of research gives an insight into what teachers advocate for inclusion in a curriculum, it does not provide much insight into what history teachers actually do teach.

\section{Content and its 'usability'}

It has been argued that much history teaching lacks relevance to students as it appears to have little immediate connection to their lives and today's society (van Straaten, Wilschut \& 
Oostdam, 2016). Yet 'relevance' opens up a series of complex questions - relevant to whom and to what, for example. An associated debate has focused on the need for history to provide a framework of knowledge, which young people are able to use to orient themselves in time and to make connections between past, present and potential future actions. This framework is seen as 'usable'. Yet existing curricula may provide students with disconnected 'bits-andpieces of knowledge' (Shemilt, 2009, p.142) rather than a coherent framework, leading them to doubt the value of school history even if they enjoy it (Harris \& Haydn, 2006).

Even among those who advocate designing a curriculum to develop such a frame of reference there are differences of opinion about what sort of framework should be developed, which focus on scale and nature. The debate about scale refers to how much history and which geographical areas should be included. One possible framework could focus on developing a coherent, chronological narrative of the national past, a stated aim of the new history curriculum (DfE, 2013b). Shemilt (2009), however, advocates helping students develop a larger scale framework based upon four broad themes covering the span of human history (modes of production, political and social organisation, growth and movement of peoples and culture and praxis). The debates about the nature of a framework focus on two interconnected questions. Firstly, is a framework best constructed chronologically or thematically, and secondly, is it an 'object' or 'instrument' of learning (Howson \& Shemilt, 2011)? Dawson (2008) advocates studying chronological thematic stories, such as the development of democracy. However Howson and Shemilt (2011) critique this approach for being episodic and presenting the past as a fixed line of development (i.e. creating an 'object' of learning). Instead they see a framework being taught rapidly at the start of a unit of work, and which is provisional and open to change as students gain new knowledge and insights. As yet there have been few evaluations of these different approaches to developing a coherent framework of knowledge to determine which is most appropriate. 
From this review it can be seen that there are different positions regarding the content of history curricula and how they should be implemented. At the same time, the positions of teachers themselves within such debates is unclear and we have limited insights into what practitioners actually choose to teach or how. The extent to which history teachers adopt a disciplinary approach to teaching, what content they choose to include, and whether they are consciously thinking about content selection with a view to developing a usable framework of knowledge, are all issues requiring further exploration.

\section{Research aims}

The aim of this research was to better understand practitioners' decision making by exploring the following research questions in relation to a group of history teachers:

1. To what extent do these teachers explicitly teach history as a disciplinary form of knowledge?

2. What substantive content do they choose to include in what they teach?

3. What approaches to developing a substantive framework of knowledge do these teachers adopt?

To answer these questions it was important to draw upon the actual experience and views of history teachers in relation to their planned curricula.

\section{Methodology}

The choice of participants was both purposive and convenient (Robson, 2002). It was purposive as the teachers who were approached were heads of history in state-maintained schools, and it was convenient as they were located within two counties in the south of England to allow ease of access to collect data. Around 100 heads of history were invited by letter to participate and 11 members of staff from ten schools agreed to take part. Given the 
nature of the approach to obtaining participants no claim to generalisability is made. Instead the findings reflect what was encountered in these particular contexts, at a time of curriculum change.

Participants taught in schools in a range of settings. The schools served a range of socio-economic catchments, were in urban or sub-urban areas, whilst the grades from Ofsted, a regulatory body that inspects the quality of schools, were varied (half were outstanding or good and the other half were judged to require improvement). Five were comprehensive schools and five were academies (and were therefore not required to follow the National Curriculum).

Two forms of data were collected, namely documentary evidence in the form of schemes of work and semi-structured interviews. Schemes of work are working documents, produced by teachers, outlining what they intend to teach in the medium and long term, and in what way. As it was not possible to observe teachers over any length of time actually enacting these schemes of work, the decision was taken to use them as indicative of what the intended curriculum was to be, so it has to be acknowledged that this was an interpretative exercise. The schemes varied in level of detail, but generally included the substantive content to be taught, the aims of particular lessons, and many also provided suggested activities and resources. This combination of features gave a good indication as to the nature of what was intended.

Schemes examined were for pupils aged $11-13 / 14$ as this is when history is a compulsory subject in the secondary school curriculum. All schools provided copies of their schemes of work, although one was incomplete as the department was still in the process of updating theirs in light of recent curriculum changes. For the purposes of this paper, the majority of the findings draw on these schemes of work. 
To further explore what teachers chose to teach and what approaches they adopted a semi-structured interview approach was used, with interviews conducted on the school premises and lasting around 30 minutes. The questions posed that are explored for the purpose of this paper covered the following: the reasons behind the choice of topics taught to students in KS3 and whether some of these reasons were more important than others; whether there had been any changes/additions to the topics taught at KS3 in the past 3-4 years, what these were and why new topics were introduced.

Ethical approval for the project was granted by the university in which the researchers were based, following its procedures and those of the British Educational Research Association (BERA) (2011). Informed consent was obtained from each participant, and agreement received to electronically record interviews. Copies of the transcripts were made available to all participants for validation.

The schemes of work were coded deductively, using ideas from the literature, to answer research questions 1 and 3. For example instances where there was a clear focus (in the question/topic heading in the scheme of work and/or learning objectives) on second-order or procedural ideas, such as causation or use of evidence, would be interpreted as a disciplinary approach, whereas examples where content was identified was regarded as a substantive approach (see Appendix A for an example of this coding). The schemes of work were also subject to content analysis (Robson, 2002) to answer question 2, which essentially identified the frequency with which topics were taught.

The analysis of the teachers' transcripts was an iterative process, using ideas from the literature and repeated reading of the transcripts to generate codes (Robson, 2002). To ensure the codes were robust, a constant comparative approach was adopted, so that the codes generated from one transcript were tested on new transcripts. As the interviews covered a range of issues beyond those reported here, only comments pertinent to the focus of this 
paper are included. For research question 1 these comments relate to history as a body of knowledge (i.e. emphasis on learning substantive knowledge) and a form of knowledge (i.e. reference to second-order concepts and how history is constructed). For question 3 comments were coded as adopting a chronological framework and a thematic approach.

\section{Findings}

\section{To what extent do these history teachers explicitly teach history as a disciplinary form of knowledge?}

There was evidence of a strong disciplinary focus in half of the departments' planning. Table 1 shows how Apple School and Lemon School approached a unit on medieval Britain. In both cases it is assumed that students would be taught pertinent substantive content. In Apple School there is an explicit disciplinary approach with a stronger emphasis on enquiry questions and objectives phrased around second-order concepts and processes. Lemon School in contrast has a stronger emphasis on topics and key features and events within those, and only occasionally makes reference to specific second-order concepts. This was also evident in interview. For example, Alison (Apple School) referred to developing students' ability to 'handle evidence' and 'managing different points of view', whereas Gemma (Lemon School) kept focusing on the topics she wanted students to learn about.

[Table 1 near here]

In total, analysis showed that in five schools the schemes of work showed a strong disciplinary approach to the teaching of history, reflecting the approach of Apple School shown in Table 1. In these five schools the majority of lessons focused on second-order concepts or processes. Three schemes of work from other schools were characterised by an emphasis on historical topics and key events or features that students were expected to know about. The schemes of work from the other two schools were more mixed. In one case the 
work designed for students aged 11-12 was presented largely as a series of topics whereas the work for students aged 12-14 was set out as a sequence of enquiries; this may reflect the fact that this department was in a state of flux and the schemes of work were undergoing revision. In the other case the schemes of work were based around enquiry questions which ran for several weeks, but the individual lessons within each extended enquiry were often presented as topics. For example an enquiry question on 'How hard was life for ordinary people in the Middle Ages?' listed topics such as crime and punishment, entertainment, and health. The assessment task for this sequence of lessons was then to create an historical travelogue of the lives of ordinary people, emphasising the predominantly factual nature of these lessons. There was also congruence between the schemes of work and what teachers said in the interviews. Those teachers who spoke most explicitly about history as a discipline had schemes of work that reflected this. For example Tanya's schemes of work at Plum School had a strong disciplinary focus, reflecting her view that 'history is a discipline, and it needs to be taught as a discipline'.

Interestingly in those departments with a strong emphasis on disciplinary thinking, there were differing degrees of emphasis on second-order concepts and processes. Secondorder concepts, such as cause and consequence, and change and continuity, essentially require students to analyse and explain events and phenomena, whereas a focus on using sources and examining historical interpretations focuses more on how the past is constructed (although it is acknowledged, as Ashby (2017) argues, there is also a conceptual side to evidential work). Plum School illustrates the nuances possible within a disciplinary approach (Table 2). Its unit of work on Anglo-Saxons is atypical amongst those analysed for its strong emphasis on using sources to understand how knowledge of the past is constructed. For example the question 'How can Sutton Hoo help us learn about the Saxons?' requires students to infer, synthesise and construct possible meanings from artefacts, and makes 
students consider issues such as the usefulness of different types of source. By contrast its unit on Medieval Britain is more typical, as most schools identified as adopting a disciplinary approach placed more emphasis on second-order concepts. For example, Ash School's unit on medieval Britain included 16 lessons focusing on concepts such as causation, change and continuity, whereas six lessons focused on working with sources and only one on historical interpretations.

[Table 2 near here]

Overall causation questions dominated the majority of the schemes of work which had a disciplinary focus. Enquiries about historical interpretation, which has been valued for showing how history is fluid, featured infrequently in the schemes of work. Where they did appear they were invariably linked to individuals such as King John and Oliver Cromwell.

\section{What substantive content do these teachers choose to include in what they teach?}

From the analysis of the schemes of work there emerged a degree of commonality between schools regarding topics included, especially for the medieval and early modern periods (see Table 3). The coverage of medieval English history focused heavily on the Norman Conquest, development of castles, struggles between the Church and State (characterised by lessons on Henry II's quarrel with Thomas Becket), the Magna Carta, the Black Death and the Peasants' Revolt. The remaining topics reflect individual preferences. The detail in which the topics were covered was more difficult to decipher as not all schemes of work indicated a timescale, but from those that did it was clear there was great variation - Cherry School and Apple School both taught the medieval period in 15 lessons, whereas Ash School devoted 52 to the period. It would however seem that for periods such as the Middle Ages there was a largely uniform set of topics, effectively forming an unofficial "canon". Given that the 2014 National Curriculum does not specify particular topics that have to be taught, and as five of 
the schools are academies and have complete freedom over what to teach, the degree of consistency between schools is interesting. Additionally the majority of the topics chosen focus on English history and political history.

[Table 3 near here]

This consistency could also be seen in the topics covering the sixteenth and seventeenth centuries. All the teachers taught about the English Reformation, and the English Civil War, and there was also a strong focus on Elizabeth I, Oliver Cromwell and the Commonwealth period and the Restoration. While there was some variation in the number of lessons devoted to the period (from 12 to28), there was general uniformity in the body of events taught. Again the topics were largely focused on English, political history.

There was more variety in the topics included for later historical periods. All the teachers taught about the Industrial Revolution and generally looked at social and economic changes, but some also included a political element, often linked to the campaign for female suffrage. However few teachers devoted much time to this period; on average it was dealt with in about 10-12 lessons, and in one case was set purely as an extended homework topic. The focus on the twentieth century was strongly centred on World War I (WWI) and World War II (WWII), and seldom ventured beyond 1945 in much depth; typically the emphasis of the WWI topic was on its causes and the nature of the fighting (although very much from a Western Front perspective), whereas teaching about WWII tended to show a more eclectic approach to the topic.

Surprisingly, given the Holocaust has been one of the few topics that has consistently been a compulsory part of the history National Curriculum, four schools made no mention of it in their schemes of work. Where it was included most schools allowed 2-4 lessons to teach it. Two schools gave it more consideration. Plum School provided at least 10 lessons to cover this topic, whilst Oak School incorporated it into a unit on 'oppression and resistance'. 
Few teachers had incorporated much local history into their curriculum. Charles at Oak School included an opportunity for students to study the history of their town in depth as a standalone topic, whilst Gemma at Lemon School had woven it into what she covered. However Tanya included a more substantial amount of local history. She argued that its inclusion made the study of history appear more relevant to students. Although other teachers in the study were in the same area as Plum School they had not chosen to exploit local history in the same way; this seems to be a missed opportunity as other studies (e.g. Haydn \& Harris, 2010) have shown that many students fail to connect with the history they are taught as it often seems remote from their experience of life, and potentially a greater focus on local history might be a way to address this.

Wider world history was also conspicuous by its relative absence; it either appeared under the guise of Roman history, the Trans-Atlantic slave trade and black civil rights in America, European dictators of the C20th and the Cold War. Some teachers, such as Alison (Apple School) acknowledged in the interview that more and wider world history ought to be included.

\section{What approaches to developing a substantive framework of knowledge do these teachers} adopt?

As shown in Table 4 most teachers adopted a chronological or episodic approach, even if the curriculum does provide scope to teach history thematically. Evidence for a chronological or episodic approach was clear from the interview data, and was also discernible in the schemes of work where it could be seen whether topics were set out sequentially or thematically. For example Kerry, at Ash School, explained in her interview that a thematic approach involved 'too much hopping around', basing her view from her personal experience of being taught the history of medicine through time. 
Five of the teachers used themes, but in different ways. Gemma (Lemon School) reported taking one theme, the history of medicine, and threaded it into all the different periods studied across the course of the curriculum; otherwise the curriculum was chronologically constructed. George at Elm School said he used an overarching theme across a year to tie chronologically taught topics together. For example he commented that the theme of the authority of the state and the rights of man unified topics from 1500-1900. He took this approach because:

[the students] don't seem to know much history and I would like them to remember more and the reasons how things are connected, so I wanted to give them a vehicle, a mechanism for them to understand a broad concept of change over time.

[Table 4 near here]

Tanya at Plum School said her teaching was based around big themes, such as movement and settlement, migration, and power. Alison at Apple School also claimed to adopt themes but these were not explicit in the schemes of work she shared. The most obviously thematic approach was that adopted by Jane at Orange School in her planning; she explained she wanted to cover themes such as society through time, medicine, religion, technology, empire, politics and warfare, but in a broad chronological outline. In her interview, she admitted this created a 'very content heavy' curriculum, which was reinforced through frequent knowledge tests, but meant that students' 'chronological [understanding] is now highly improved and their sense of what comes when and so that's really important.' Of all the schemes of work analysed this one stood out as being obviously different in the thinking behind its structure, with a deliberate intention to build a thematically constructed narrative framework.

Jane's emphasis on looking at topics largely in outline also differs from the approach of other teachers. Most teachers in this study appeared to have looked at issues and events in depth, with only the occasional overview lesson built in to provide context. This suggested 
few had fully embraced the thinking behind Riley’s (1997) approach, which advocates a judicious combination of depth and overview. A heavy emphasis on depth studies was evident in four teachers' planning - Christopher, Emily, Judith and Kerry - whilst Alison, Charles, Gemma and George's thinking tended to focus more on depth studies with an occasional use of overviews. Tanya's planning tended to show the greatest balance in this regard, whereas Jane felt her job was to include mainly overviews. Overall these findings suggest that teaching thematically or with overviews was limited, so there was little explicit emphasis on the idea of developing an overarching, coherent framework knowledge for students. Instead the focus was very much on the use of depth studies.

\section{Discussion}

In relation to the issues identified in the literature around teaching history as a discipline, exploring what is taught and how teachers are trying to construct frameworks of knowledge, this study highlights some interesting points. Although the size of the study means it is not possible to make claims about how common these issues are, the study does raise questions that are worth further exploration.

There has been a well-established emphasis in England on teaching history as a discipline (Cercadillo, 2015), yet this study questions what this means in terms of classroom practice. Although it is clear in many schools that the analytical structures of history as a discipline, i.e. causation, change and continuity, are the focus of much attention, other aspects of history as a discipline feature less heavily, namely the way in which claims about the past are established and contested. More emphasis on the process by which history is constructed would provide students with clearer access to what Young (2011) calls 'powerful knowledge', by giving them an appreciation of how knowledge is produced and how claims to 'truths' have to be warranted but are also subject to modification. Both of these would be 
important educational goals. Where teachers in this study did talk about working with evidence it was more in terms of generic 'skills' rather than related specifically to the use of evidence in developing historical claims.

In terms of content selection there is a large degree of consistency across the different schemes of work, which also suggests continuity within the curriculum. Generally speaking what was covered was largely English history, and much of this tended to have a political focus. This reflects Cannadine, Keating and Sheldon's (2011) findings about what is typically taught in schools nowadays and which they feel is often episodic and lacking coherence. This lack of coherence can be seen in the big differences between schools in the study regarding how much time they are able to devote to different periods of history, an issue that has been highlighted as affecting numerous schools (e.g. Burn \& Harris, 2011). There also appears to be much uniformity in terms of what is taught. Content related to medieval and early modern Britain is remarkably similar between departments and is consistent in terms of what was originally specified in earlier iterations of the history National Curriculum. More modern history is also overwhelmingly focused on particular topics. It does seem that a particular consensus about historical content in these schools has been enshrined, with a few exceptions. Whether this is the 'right kind of history' is a moot point; clearly there is a lot of history to choose from when it comes to teaching but, especially with the modern topics, there are surprising omissions in some departments' work, such as the Holocaust, whilst the lack of topics beyond 1945 means that topics of contemporary significance are not able to be explored.

The chronological and episodic construction of the curricula in these schools also has implications for how students might see history as 'usable'. Few of the teachers included much of a focus on overviews, which are seen as a way of providing a means of 'knitting' the past together and showing how events relate to each other, and even fewer seemed to have an 
explicit focus on providing a 'big picture' of the past. Developing this is considered an essential step in improving history education (e.g. Shemilt, 2009) to demonstrate to students that history is valuable, by allowing them to orientate themselves in time and seeing possible futures. In many ways the lack of teacher engagement with this issue is not unexpected because as yet there has been little clear direction as to how best to develop a framework of knowledge apart from some small practitioner-based studies (e.g. Nuttall, 2013).

In terms of teacher development, Biesta et al. (2015) argue that current trends in education policy, such as the growth of accountability, mean teachers are driven by shortterm goals, rather than by the broader significance of their work, and therefore tend not to consider bigger issues, such as content selection. Instead debates about content are increasingly left to governments to decide. Yet as Cannadine et al. (2011, p.233) argue, in many ways the curriculum documents issued by government ministries are not that important, what matters is what teachers do with the documents. Some of the teachers in this study, notably George, Jane and Tanya, have managed to construct curricula which offer alternative conceptions of what the curriculum could look like, and by debating and sharing such ideas teachers can be empowered to see themselves as 'curriculum makers' (Lambert $\&$ Biddulph, 2015). Exploring issues related to content selection and encouraging teachers to engage more explicitly with such debates does seem to be a fruitful way forward.

\section{References}

Anderson, G. (2015). What is knowledge in English and where does it come from? Changing English, 22 (1), 26-37. doi: 10.1080/1358684X.2014.992203.

Ashby, R. (2017). Understanding historical evidence: teaching and learning challenges. In I. Davies (Ed.), Debates in history teaching ( $2^{\text {nd }}$ edn.) (pp.144-154). London: Routledge. 
Barton, K. (2009). The denial of desire: how to make history education meaningless. In L. Symcox \& A. Wilschut (Eds.), National history standards: The problem of the canon and the future of teaching history (pp.265-282). Charlotte, NC: Information Age.

Beck, J. (2013). Powerful knowledge, esoteric knowledge, curriculum knowledge. Cambridge Journal of Education, 43 (2), 177-193. doi: 10.1080/0305764X.2013.767880.

BERA (2011). Ethical guidelines for educational research. London: BERA.

Biesta, G., Priestley, M. \& Robinson, S. (2015). The role of beliefs in teacher agency. Teachers and Teaching: Theory and practice, 21 (6), 624-640. doi: 10.1080/13540602.2015.1044325

Boschman, F., McKenney, S., \& Voogt, J. (2014). Understanding decision making in teachers' curriculum design approaches. Education Technology Research Development, 62, 393-416. doi:10.1007/s11423-014-9341-x

Burn, K. and Harris, R. (2011) Historical Association Survey of History in Schools in England 2011. London: Historical Association. Retrieved from:

http://www.history.org.uk/resources/secondary news 1290.html

Cain, T., \& Chapman, A. (2014). Dysfunctional dichotomies? Deflating bipolar constructions of curriculum and pedagogy through case studies from music and history. The Curriculum Journal, 25, 111-129. doi: 10.1080/09585176.2013.877396

Cannadine, D., Keating, J., \& Sheldon, N. (2011). The right kind of history. Basingstoke: Palgrave MacMillan.

Cercadillo, L. (2015). Teachers teaching history in Spain: Aims, perceptions, and practices on second order concepts. In A. Chapman \& A. Wilschut (Eds.), Joined-up history (pp.115-136). Charlotte, NC: Information Age Publishing Inc.

Dawson, I. (2008). Thinking across time: Planning and teaching the story of power and democracy at Key Stage 3. Teaching History, 130, 14-21. Retrieved from www.history.irg.uk

DfE (2013a). The National Curriculum in England: Framework document for consultation. Retrieved from https://media.education.gov.uk/assets/files/pdf/n/national\%20curriculum\%20consultation\%20\%20framework\%20document.pdf

DfE (2103b) History programmes of study: key stage 3 National Curriculum in England. Retrieved from

https://www.gov.uk/government/uploads/system/uploads/attachment_data/file/239075/SECONDARY national curriculum - History.pdf. Accessed 01.04.15 
Harris, R. (2012). 'Purpose' as a way of helping white trainee history teachers engage with diversity issues. Education Sciences, 2, 218-241. doi:10.3390/educsci2040218.

Harris, R., \& Burn, K. (2011). Curriculum theory, curriculum policy and the problem of illdisciplined thinking. Journal of Education Policy, 26, 245-261. doi:

10.1080/02680939.2010.498902

Harris, R., \& Burn, K. (2016) English history teachers' views on what substantive content young people should be taught. Journal of Curriculum Studies, 48 (4), 518-546. doi: $10.1080 / 00220272.2015 .1122091$

Harris, R. \& Haydn, T. (2006). Pupils' enjoyment of history: what lessons can teachers learn from their pupils?. The Curriculum Journal, 17 (4), 315-333. doi:

$10.1080 / 09585170601072544$

Haydn, T., \& Harris, R. (2010). Pupil perspectives on the purposes and benefits of studying history in high school: a view from the UK, Journal of Curriculum Studies, 42 (2), 241-261. doi: 10.1080/00220270903403189

Hirsch, E.D. (1987). Cultural literacy: What every American needs to know. New York: Vintage Books.

Howson, J., \& Shemilt, D. (2011). Frameworks of knowledge: Dilemmas and debates. In I. Davies (Ed.), Debates in history teaching (pp.73-83). Abingdon: Routledge.

Husbands, C., Kitson, A., \& Pendry, A. (2003). Understanding history teaching: Teaching and learning about the past in secondary schools. Maidenhead: Open University Press.

Lambert, D., \& Biddulph, M. (2015). The dialogic space offered by curriculum-making in the process of learning to teach, and the creation of a progressive knowledge-led curriculum. Asia-Pacific Journal of Teacher Education, 43 (3), 210-224. doi: 10.1080/1359866X.2014.934197

Macaro, E. (2014). Grammar: The never-ending debate. In P. Driscoll, E. Macaro \& A. Swarbrick (Eds.), Debates in modern language teaching (pp.108-120). London: Routledge.

Mitchell, D., \& Lambert, D. (2015). Subject knowledge and teacher preparation in English secondary schools: The case of geography. Teacher Development, 19 (3), 365-380. doi: $10.1080 / 13664530.2015 .1042024$

Monte-Sano, C., de la Paz, S., \& Felton, M. (2014). Implementing a disciplinary-literacy curriculum for US history: Learning from expert middle school teachers in diverse classrooms. Journal of Curriculum Studies, 46 (4), 540-575. doi: 10.1080/00220272.2014.904444 
Nakou, I., \& Barca, I. (2010). Contemporary public debates over history education. Charlotte, NC: Information Age Publishing.

Nuttall, D. (2013). Possible futures: using frameworks of knowledge to help Year 9 connect past, present and future. Teaching History, 151, 33-44. Retrieved from www.history.org.uk

Ormond, B.M. (2016). Curriculum decisions - the challenges of teacher autonomy over knowledge selection for history. Journal of Curriculum Studies, in press. doi: 10.1080/00220272.2016.1149225

QCA (2007). History: programme of study for key stage 3 and attainment target. London: QCA.

Riley, M. (1997). Big stories and big pictures: Making outlines and overviews interesting. Teaching History, 88, 20-22. Retrieved from www.history.org.uk

Robson, C. (2002) Real world research. (2 ${ }^{\text {nd }}$ ed.). Oxford: Blackwell Press.

Sandwell, R. (2012). 'We were allowed to disagree, because we couldn't agree on anything': Seventeen voices in Canadian debates over history education. In T. Taylor \& R. Guyver (Eds.) History wars and the classroom: Global perspectives. Charlotte, NC: Information Age.

Sears, A. (2017). Trends and issues in history education in international contexts. In I. Davies (Ed.), Debates in history teaching ( $2^{\text {nd }}$ edn.) (pp. 42-52). London: Routledge.

Seixas, P. (2007). Who needs a canon? In M. Grever \& S. Stuurman (Eds.) Beyond the canon: History for the twenty-first century (pp.19-30). Basingstoke: Palgrave Macmillan.

Shemilt, D. (2009). Drinking an ocean and pissing a cupful: How adolescents make sense of history. In L. Symcox \& A. Wilschut (Eds.), National history standards: The problem of the canon and the future of teaching history (pp.141-210). Charlotte, NC: Information Age Publishing Inc.

Swalwell, K., Pellegrino, A.M., \& View, J.L. (2015). Teachers' curricula choices when teaching histories of oppressed people: Capturing the US Civil Rights Movement. Journal of Social Studies Research, 39, 79-94. doi: 10.1016/j.jssr.2014.11.003

Van Straaten, D., Wilschut, A.,\& Oostdam, R. (2016). Making history relevant to students by connecting past, present and future: A framework for research. Journal of Curriculum Studies, 48 (4), 479-502. doi: 10.1080/00220272.2015.1089938

Young, M. (2011). The return to subjects: A sociological perspective on the UK Coalition government's approach to the 14-19 curriculum. The Curriculum Journal, 22, 265-278. doi: $10.1080 / 09585176.2011 .574994$ 
Young, M. (2013). Powerful knowledge: an analytically useful concept or just a 'sexy sounding term'? A response to John Beck's 'Powerful knowledge, esoteric knowledge, curriculum knowledge'. Cambridge Journal of Education, 43 (2), 195-198. doi:10.1080/0305764X.2013.776356.

Young, M. (2014). What is a curriculum and what can it do? The Curriculum Journal, 25 (1), 7-13. doi: $10.1080 / 09585176.2014 .902526$

Young, M., \& Muller, J. (2010). Three educational scenarios for the future: Lessons from the sociology of knowledge. European Journal of Education, 45, 11-27. doi: 10.1111/j.14653435.2009.01413.x 